\title{
RELATO DE CASO: A ATUAÇÃO DO ENFERMEIRO EXCLUSIVO PARA O ATENDIMENTO NO TIME DE RESPOSTA RÁPIDA EM UM HOSPITAL ONCOLÓGICO DE SÃO PAULO
}

\section{INTRODUÇÃO E OBJETIVO}

Implantado em um hospital oncológico, o Time de Resposta Rápida (TRR) é composto por enfermeiros exclusivos para esse fim. Esses enfermeiros tem como escopo a atuação em situações de urgência/ emergência de pacientes que estão fora da Unidade de Cuidados Intensivos.

A necessidade do atendimento exclusivo surgiu devido às características dos pacientes oncológicos, com predisposição aos fatores causados pela evolução da patologia e do tratamento.

Critérios para fazer parte da equipe:

-Enfermeiros com experiência de atuação e especialização na área de Emergência, UTI e/ou cardiologia;

- Enfermeiros com certificação pela American Heart Association (AHA) e treinamento anual de Suporte Avançado de Vida em Cardiologia (ACLS).

\section{MATERIAL E MÉTODOS}

A ação dos enfermeiros do TRR se inicia nos primeiros sinais e sintomas de deterioração, gerando assim barreiras para identificação e tratamento precoces, melhorando o desfecho das intercorrências e evitando evoluir para cenários mais graves, como a Parada Cardiorrespiratória (PCR).

Seguem métodos de acionamento dos enfermeiros TRR:

-Protocolo MEWS/ Sepse 3.0 através do Sistema de Informação Hospitalar;

-Acionamento pelo ramal móvel quando equipe identifica potenciais benefícios da ação do TRR;

-BIP exclusivo para acionamento em casos de PCR.

Todo atendimento realizado pela equipe do TRR é registrado em documentos/impressos próprios.

\section{RESULTADOS E DISCUSSÃO}

\section{Benefícios/ganhos com enfermeiro exclusivo no Time de Resposta Rápida}

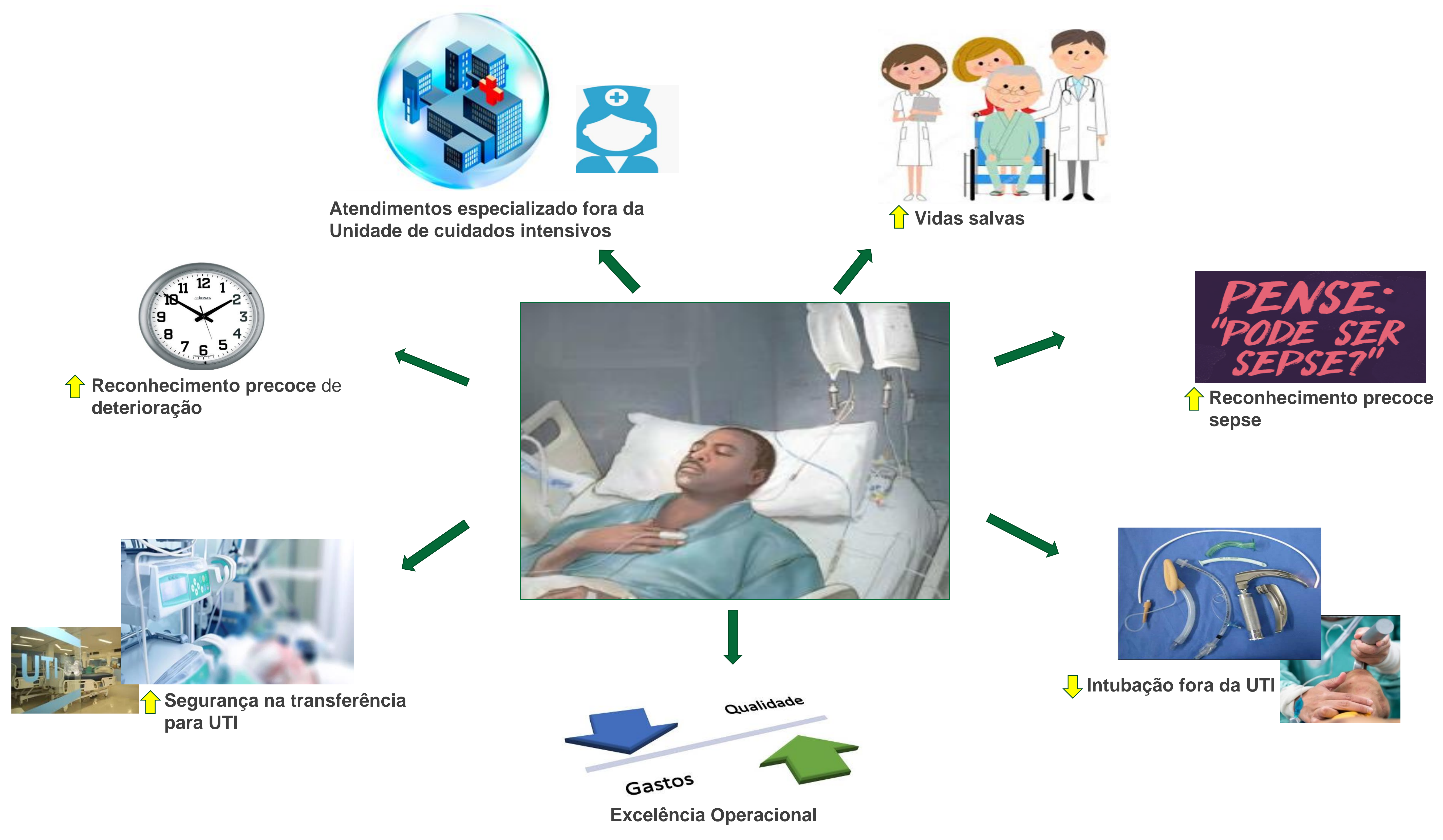

\section{CONCLUSÃO}

Observa-se a consolidação das ações do TRR através do crescimento do número de acionamentos do time pelas equipes. Comparando ago/set/out de 2017, com uma média/mês de 24,66 acionamentos, com os mesmos meses de 2018, observa-se que a média/mês passou para 35,33. Também foi observado aumento na conformidade do atendimento ao protocolo MEWS/SEPSE e diminuição na Unidade de Internação (UI) de IOT, PCR e transferência precoce de pacientes para a UTI. Essas melhorias resultam em qualidade na assistência prestada, gerando uma maior sobrevida aos pacientes. Além disso houve redução de custos com atendimentos urgenciais e uso de UTI. Atualmente os enfermeiros exclusivos do TRR atuam no período diurno, exceto finais de semana, e está em discussão a necessidade de expansão do atendimento para 24 horas/ 7 dias da semana. 